\title{
Reproductive Hormones and Their Receptors May Affect Lung Cancer
}

\author{
Mengmeng Dou ${ }^{a}$ Keyan Zhu ${ }^{a}$ Zhirui Fan ${ }^{b}$ Yuxuan Zhang ${ }^{a}$ Xiufang Chen ${ }^{c}$ \\ Xueliang Zhou ${ }^{b}$ Xianfei Ding ${ }^{d}$ Lifeng Lib Zhaosen Gua Maofeng Guo ${ }^{\mathrm{e}}$ Ming Yan $^{\dagger}$ \\ Xiaoming Deng ${ }^{a}$ Peihong Shen ${ }^{f}$ Shuling Wang ${ }^{\mathrm{e}}$
}

a Department of Integrated Traditional and Western Medicine, ${ }^{b}$ Department of Oncology, The First Affiliated Hospital of Zhengzhou University, Zhengzhou, 'Department of Internal Medicine, Zhengzhou Xinhua Hospital of Traditional Chinese Medicine, dDepartment of General ICU, The First Affiliated

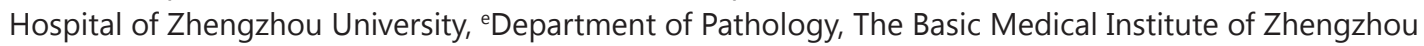

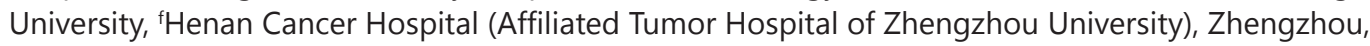
China

\author{
Key Words \\ Ovariectomized mice • Oestradiol • Testosterone • Lung cancer
}

\begin{abstract}
Background/Aims: In contrast to men, women have experienced a rapid increase in lung cancer mortality. Numerous studies have found that the sex differences in lung cancer are due to reproductive hormones. Experiments in female mice with and without ovariectomy were performed to explore the possible mechanism by which sex hormones (and their receptors) influence lung cancer. Methods: Twenty-four female C57BL/6 mice aged 56-62 days were randomly divided into the ovariectomized group and the control group. In the ovariectomized group, the bilateral ovaries were removed via the dorsal approach, while the control group underwent a sham operation with bilateral ovarian fat resection at the same sites. After 3 weeks of recovery, Lewis lung cancer cells were transplanted into these mice by subcutaneous inoculation of a tumour cell suspension to establish the ovariectomized lung cancer model. Beginning on the $6^{\text {th }}$ day after subcutaneous inoculation, mouse weight and transplanted tumour volume were measured every 3 days. After 3 weeks, all the mice were killed by cervical dislocation, and we measured the tumour weight. Mouse serum and tumour tissues were removed. Then, the serum levels of $\mathrm{E}_{2}$ (oestradiol) and $\mathrm{T}$ (testosterone) were detected by ELISA; the protein expression levels of AR (androgen receptor), ER $\alpha$ (oestrogen receptor $\alpha$ ) and ER $\beta$ (oestrogen receptor $\beta$ ) were detected by Western Blot and IHC (immunohistochemistry); and the mRNA expression levels of $A R, E R \alpha$ and ER $\beta$ were detected by qRT-PCR (quantitative real-time polymerase chain reaction) in the ovariectomized and control groups. Results: Compared with the control group, both mouse weight and transplanted tumour volume increased rapidly in the ovariectomized group, and the transplanted tumour weight was significantly heavier in the ovariectomized group $(1.83 \pm 0.40$ and $3.13 \pm 0.43, P<0.05) . E_{2}$ and

M. Dou and K. Zhu contributed equally to this article.

Shuling Wang and Peihong Shen

Department of Pathology, The Basic Medical Institute of Zhengzhou University, Zhengzhou and Henan Cancer Hospital (Affiliated Tumor Hospital of Zhengzhou University), Zhengzhou 450000, (China); E-Mail wsI5869@163.com/ 13838122660@163.com
\end{abstract}

KARGER 


\section{Cellular Physiology Cell Physiol Biochem 2017;44:1425-1434 \\ \begin{tabular}{l|l|l} 
and Biochemistry $\begin{array}{l}\text { DOI: 10.1159/000485538 } \\
\text { Published online: November 30, } 2017\end{array}$ & $\begin{array}{l}\text { (c) } 2017 \text { The Author(s). Published by S. Karger AG, Basel } \\
\text { www.karger.com/cpb }\end{array}$
\end{tabular}}

Dou et al.: Reproductive Hormones May Affect Lung Cancer

T serum levels decreased exponentially in the ovariectomized group, while the $E_{2} / T$ ratio increased compared with the control group $\left(E_{2}: 55.88 \pm 11.45\right.$ and $78.21 \pm 9.37 ;$ T: $0.82 \pm 0.14$ and $1.46 \pm 0.16$; ratio: $69.62 \pm 14.43 \pm 29.81$ and $52.22 \pm 5.42$; all $P<0.05)$. The Western blot and $I H C$ results indicated that $A R, E R \alpha$ and $E R \beta$ protein expression levels were obviously higher in transplanted tumour and lung tissues from the ovariectomized group, with particular increases in ER $\beta$ in transplanted tumour tissue and in ER $\alpha$ in lung tissue. The PCR results also showed markedly higher mRNA expression levels of $A R, E R \alpha$ and $E R \beta$ in the ovariectomized group, and in particular, ER $\beta$ in transplanted tumour tissue and $E R \alpha$ in lung tissue were significantly increased in the ovariectomized group. Conclusion: Ovariectomy decreased $E_{2}$ and $T$ serum levels and increased the $E_{2} / T$ ratio in mice, and this imbalance in the internal environment promoted the growth of transplanted tumours. Sex hormone disorder not only promoted transplanted tumour growth but also significantly reduced the protein and mRNA expression levels of sex hormone receptors. The metabolism of $E_{2}$ and $T$ may affect the growth, proliferation and metabolism of lung cancer cells, and the mechanism by which sex hormones and their receptors influence lung cancer is worthy of further research.

(C) 2017 The Author(s)

Published by S. Karger AG, Basel

\section{Introduction}

Lung cancer remains the leading cause of cancer-related death globally, and outcomes for patients diagnosed with advanced non-small cell lung cancer (NSCLC) are poor despite recent advances in treatment[1]. In 2016, there were 222,500 new cancer cases and 155,870 cancer deaths related to the lung and bronchus system in the United States. In contrast to the steady increase in survival for most cancers, that for lung cancer has been slow, with a current 5-year relative survival of 18\%[2]. There are a number of factors associated with the poor prognosis, such as drug resistance[3] and gender and age differences[4]. For a majority of patients, the disease condition is initially chemosensitive but then relapses with acquired chemoresistance[3]. The low survival rate of patients suffering from lung cancer is caused mainly by delayed detection and diagnosis, resulting in the identification of disease at an advanced stage and leaving the patient with limited treatment options[5].

Although some molecular alterations[6, 7] are shared among various histologic subtypes of cancer, the majority of genomic alterations remain distinct[8]. Accumulating evidence[9-13] indicates that the presence and progression of lung cancer is affected by gender-dependent factors, especially oestrogens. Oestrogens affect cellular processes by binding to oestrogen receptors (ERs) and signalling in two different ways: genomic and nongenomic[14]. In genomic signalling, oestrogens bind to ERs, mainly ER $\alpha$ and ER $\beta$, which causes ER dimerization, translocation to the nucleus and binding to specific DNA regions known as oestrogen response elements (EREs) $[15,16]$.

Some modern medical studies[14, 17, 18] have shown that sex hormones play an important role in the development of lung tissue, the formation of lung inflammation and perhaps the molecular biology of lung cancer. Many researchers found that the outcomes of patients with lung cancer were related to the use of anti-oestrogens[19]. Fan S et al also reported that ER $\beta$ activation in lung cancer cells promotes metastasis by increasing the expression of MMP-2, which is associated with cellular invasiveness[20]. Thus, sex hormones and their corresponding receptors may be potential molecular biomarkers that predict the occurrence, development, treatment, and prognosis of lung cancer.

Herein, we established a sex hormone deficiency model in C57BL/6 female mice by ovariectomy. After subcutaneous inoculation of a tumour cell suspension in all mice, body weight, transplanted tumour volume and weight, serum levels of oestradiol $\left(\mathrm{E}_{2}\right)$ and testosterone $(\mathrm{T})$ and ER expression were determined to identify potential differences upon ovariectomy. In addition, the specific mechanisms by which sex hormones and their receptors influence the development of lung cancer were explored. 


\section{Cellular Physiology Cell Physiol Biochem 2017;44:1425-1434 \begin{tabular}{ll|l} 
and Biochemistry Published online: November 30, 2017 & $\begin{array}{l}\text { (c) } 2017 \text { The Author(s). Published by S. Karger AG, Basel } \\
\text { www.karger.com/cpb }\end{array}$
\end{tabular}}

Dou et al.: Reproductive Hormones May Affect Lung Cancer

\section{Materials and Methods}

\section{Animals and reagents}

Twenty-four C57BL/ 6 female mice aged 56-62 days and weighing 20 2 g were purchased from Beijing Weitong Lihua Experimental Animal Technology Company (certificate number: SCXK 2012-0001). These 24 mice were randomly divided into the ovariectomized group and the control group. Pentobarbital sodium (no. 57330, $5 \mathrm{~g}$ /bottle) was from Merck (Germany). Benzylpenicillin sodium (1600 thousand units per bottle) was from Huabei Pharmaceutical Company. Instant PBS powder (LB12231), citrate buffer powder (LB00085), neutral balsam (20160308), Haematoxylin Stain reagent (SLBK4907V) and other reagents were purchased from Zhengzhou Saiboer Biotechnology Company. Enzyme-linked immunosorbent assay (ELISA) test kits for $\mathrm{E}_{2}$ and T (KGE014 and KGE010) were purchased from R\&D Systems (USA). Polyclonal antibodies against $A R, E R \alpha$, and $\operatorname{ER} \beta$ (ab133273, ab75635, and ab3577) were from Abcam (USA).

\section{Generation of the ovariectomized mouse model}

First, all female mice were weighed and then injected with $1 \%$ pentobarbital sodium $(0.07 \mathrm{ml} / 10 \mathrm{~g})$ to induce anaesthesia. After disinfecting the mouse back, we made a small approximately 1.5 -cm incision on the left or right flank $0.5 \mathrm{~cm}$ from the intersection of the lines extending from the hind legs and the midline of the back. The skin and muscular layers were exposed sequentially, and when we pulled out the fat pad on the left or right side with forceps, the ovary and fallopian tube were exposed. The fat pad was returned to the abdominal cavity after ligating fallopian tube and removing the ovary. The two sides were treated in the same way. Lastly, we sutured the muscle layer and the epidermis continuously with absorbable sutures. The control group was treated similarly as the case group without removing the ovary or ligating the fallopian tube, namely, the fat pad was held with blunt forceps, a section of the adipose tissue was cut, and the layers were sutured continuously with absorbable sutures. To prevent infection, all mice were treated with penicillin $(60,000$ units per mouse) for seven days after surgery.

\section{Inoculating mice with Lewis lung cancer transplanted tumours}

Tumour-bearing mice with Lewis lung cancer were decapitated and then soaked in 75\% medicalgrade alcohol. After 5 minutes, we placed the mouse on a clean bench, removed the tumour, eliminated necrotic tissue and normal tissue, and selected tumour sections in good condition. The selected tumour sections were cut into small pieces with scissors and then ground with a glass homogenizer in normal saline at a 1:3 ratio of tumour (g) to normal saline (ml). Then, the mixture was filtered through a 200 mesh screen to prepare a single cell suspension, and the percentage of viable cells was greater than $95 \%$ based on $0.2 \%$ trypan blue staining. Then, we adjusted the single cell suspension to a concentration of $1 \times 10^{7}$ cells per ml. After 3 weeks of recovery from surgery, each mouse in the ovariectomized and control groups was inoculated subcutaneously with $0.3 \mathrm{ml}$ of the single cell suspension under the right axillary fold. On the $5^{\text {th }}$ day after inoculation, the subcutaneous node was palpable. In addition, beginning on the $6^{\text {th }}$ day, we measured the longest (a) and shortest diameters (b) of the transplanted tumours and weighed all mice every 3 days. We calculated the tumour volume using the following formula: $V\left(\mathrm{~mm}^{3}\right)=1 / 2 \bullet \mathrm{ab}^{2}$. The growth curve was generated based on the arithmetic mean of the weight or volume in each group. After 21 days, all the mice were weighed, blood was drawn, and the mice were killed by decapitation.

\section{Enzyme linked immunosorbent assay (ELISA)}

On the $21^{\text {st }}$ day after inoculation, all the mice in the ovariectomized and control groups were weighed. After rapidly removing the eyeball with sterile ophthalmic forceps, blood samples were collected into sterile tubes. Then, all the samples were allowed to clot for 30 minutes at room temperature before centrifugation for 15 minutes at $1000 \times \mathrm{g}$. The upper yellow-clear serum was removed, labelled and stored at $\leq-20^{\circ} \mathrm{C}$. Based on the operational guidelines for ELISA kits (KGE014 and KGE010; R\&D Systems, USA), we reconstituted the $\mathrm{E}_{2}$ and $\mathrm{T}$ standards and generated the standard curves. According to the optical density (OD) of each well at $450 \mathrm{~nm}$ and the standard curve, the serum levels of $\mathrm{E}_{2}$ and $\mathrm{T}$ could be calculated.

RNA extraction and $q R T-P C R$

Total RNA was extracted from tissues using TRIzol reagent (Invitrogen, USA), and RNA concentration and purity were detected by a UV spectrophotometer. AcDNA kit (Thermo, USA) was used for reverse transcription; 


\section{Cellular Physiology Cell Physiol Biochem 2017;44:1425-1434 and Biochemistry Published \begin{tabular}{l|l} 
DOI: 10.1159/000485538 & $\begin{array}{l}\text { (c) } 2017 \text { The Author(s). Published by S. Karger AG, Basel } \\
\text { www.karger.com/cpb }\end{array}$
\end{tabular}}

Dou et al.: Reproductive Hormones May Affect Lung Cancer

specifically, genomic DNA was removed at $42^{\circ} \mathrm{C}$ for 2 minutes, and the reverse transcription reaction was performed at $37^{\circ} \mathrm{C}$ for 15 minutes and $85^{\circ} \mathrm{C}$ for 5 seconds. Using cDNA as the template, PCR was performed with FastStart Universal SYBR Green Master Mix (Roche, USA). GAPDH expression levels were used as the internal reference. The following primer sequences were used: GAPDH 5'-GTTCCTACCCCCAATGTGTCC-3' (forward) and 5'-TAGCCCAAGATGCCCTTCAGT-3' (reverse); ER $\alpha$ 5'-CAGCAGTAACGAGAAAGGAAACA-3' (forward) and 5'-TCGGCGGTCTTTCCGTATG-3' (reverse); ER $\beta$ 5'-TGATGATGTCCCTCACGAAGC-3' (forward) and 5'-AGAACGAGGTCTGGAGCAAAG-3' (reverse); and AR 5'-AAATGGGACCTTGGATGGAGA-3' (forward) and 5 '-TTTCCCTTCAGCGGCTCTTT-3' (reverse). The relative mRNA expression levels were quantitated by the $2^{-\Delta \Delta C t}$ method. Each experiment was repeated independently three times.

\section{Western blot analysis}

When each mouse was killed by decapitation, the transplanted tumour and lung tissue were dissected and stored in liquid nitrogen. To extract total protein, we first ground the stored tissue with liquid nitrogen and then added a mixture of $10 \mu \mathrm{l}$ of phenylmethanesulfonyl fluoride (PMSF) and $990 \mu \mathrm{l}$ of RIPA, with continued grinding for 30 minutes. The obtained mixture was centrifuged for 15 minutes at $12000 \times \mathrm{g}$ at $4^{\circ} \mathrm{C}$, and the supernatants containing total protein were harvested. The bicinchoninic acid (BCA) method was used to detect the protein concentration. Laemmli sample buffer was added, and the samples were boiled. The proteins were separated by sodium dodecyl sulphate-polyacrylamide gel electrophoresis (SDSPAGE) with subsequent transfer onto a polyvinylidene difluoride (PVDF) membrane. The membranes were incubated overnight at $4^{\circ} \mathrm{C}$ with antibodies against AR (1:1000, ab133273), ER $\alpha$ (1:1000, ab75635), ER $\beta$ (1:500, ab3577) or $\beta$-actin (1:1000, GB13001-1). After subsequent incubation with secondary antibodies, the membranes were subjected to chemiluminescence detection and exposed on X-ray films. Band density was analysed by ImageJ2x software. Each experiment was repeated independently three times.

\section{Immunohistochemistry}

All the transplanted tumour and lung tissues from mice in the case and control groups were removed on ice after the mice were killed by decapitation. Then, 4- $\mu \mathrm{m}$ formalin-fixed, paraffin-embedded sections were created from these tissues. In brief, endogenous peroxidase was quenched with $3 \%$ hydrogen peroxide, and sections were incubated with normal goat serum for 30 minutes to block nonspecific antibody binding sites. Then, the sections were incubated with antibodies against AR, ER $\alpha$ or ER $\beta$ (ab133273, ab75635, and ab3577; Abcam, USA) overnight at $4^{\circ} \mathrm{C}$ and then with a biotin-free HRP-labelled polymer. DAB solution and haematoxylin were used to visualize the positive reactions. Immunohistochemical scoring was based on the staining intensity and the percentage of positively stained cells. The staining intensity was scored as follows: 0 , no staining; 1 , weakly stained; 2 , moderately stained; and 3 , strongly stained. The percentage of positively stained cells was scored as follows: $0,0 \% ; 1,1-25 \% ; 2,26-50 \% ; 3,51-75 \%$; and $4,>75 \%$. The final staining score was the product of the staining intensity score and the percent positive score: -, final staining score $<3$; + , final staining score $=3$; ++ , final staining score $=4$; and +++ , final staining score $\geq 5$. We classified positive expression as a final staining score $\geq 4$ and negative expression as $<4$ in the mouse tumour and lung tissues. Each experiment was repeated independently three times.

\section{Statistical analysis}

The data were analysed by SPSS version 17.0. The rates of positive expression of AR, ER $\alpha$ and ER $\beta$ in lung and tumour tissues from the two groups were analysed by the $\chi^{2}$ test. The median mouse body weight, transplanted tumour weight, transplanted tumour volume and $\mathrm{E}_{2}$ and $\mathrm{T}$ serum levels were analysed by the $t$ test. The data are presented as the mean \pm standard deviation, and $P<0.05$ was considered significant.

\section{Results}

Differences in mouse survival status, body weight, and transplanted tumour volume and weight

Compared with the control mice, the ovariectomized mice were timid, easily frightened and less active, and their hair colour was not as bright. On the $5^{\text {th }}$ day after inoculation of the single cell suspension, a subcutaneous node was palpated. Beginning on the $6^{\text {th }}$ day, we measured the longest (a) and shortest diameters (b) of the transplanted tumour and the mouse body weight every 3 days. We calculated the tumour volume $\left(V=1 / 2 \bullet a b^{2}\right.$, in $\left.\mathrm{mm}^{3}\right)$ 


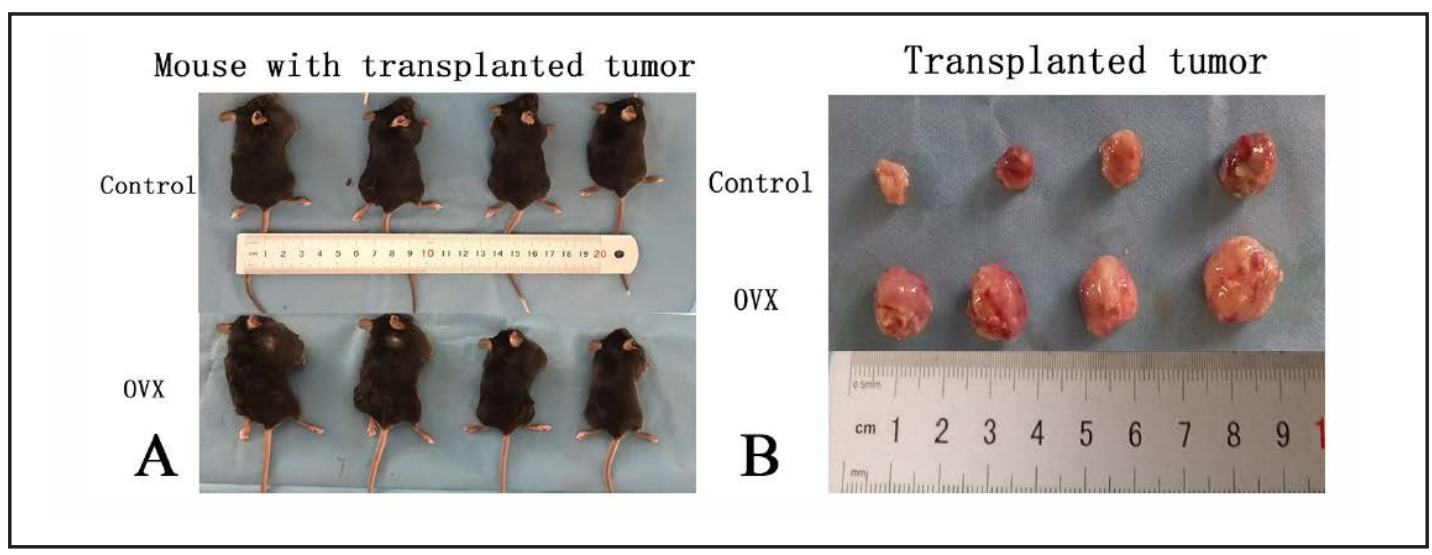

Fig. 1. Comparison of mice with transplanted tumours and the excised tumours. A: Typical pictures of mice with transplanted tumours in the control and ovariectomized groups. B: Typical pictures of excised tumours in the control and ovariectomized groups. Control: mice treated with partial bilateral fat pad removal near the ovary; OVX: ovariectomized, mice treated with bilateral ovary resection.

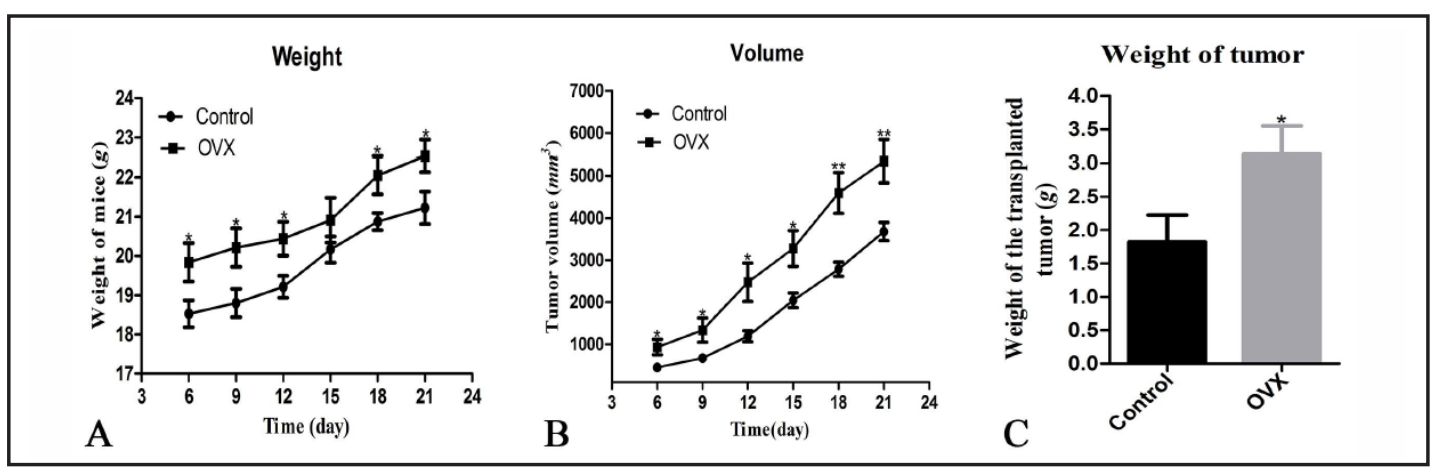

Fig. 2. Curves of mouse body weight and transplanted tumour volume and a comparison of transplanted tumour weight. The growth curves were generated based on the arithmetic mean of the weight or volume in each group. A. Curves of mouse body weight beginning at the $6^{\text {th }}$ day after inoculation with the single cell suspension. B. Curves of the transplanted tumour volume. C. Transplanted tumour weight. Control: mice treated with partial bilateral fat pad removal near the ovary; OVX: ovariectomized, mice treated with bilateral ovary resection; ${ }^{*} P<0.05,{ }^{* *} P<0.01$.

and generated a growth curve. The transplanted tumours were generally larger in the ovariectomized group than in the control group (Fig. 1). The growth curves showed that the transplanted tumours in the ovariectomized group grew faster than those in the control group $(P<0.05)$. In addition, the tumour weight differed significantly between the two groups $(1.83 \pm 0.40$ and $3.13 \pm 0.43, P<0.05)$ (Fig. 2 ).

\section{Serum levels of oestradiol $\left(E_{2}\right)$ and testosterone (T) in the two groups}

Three weeks after inoculation of the single cell suspension, blood samples were rapidly removed via retroorbital bleeding from all the mice in the two groups. The blood samples were allowed to clot for 30 minutes at room temperature and then centrifuged for 15 minutes at $1000 \times$ g. Based on the operational guidelines for the ELISA kits (KGE014 and KGE010; R\&D Systems, USA), the serum levels of $\mathrm{E}_{2}$ and $\mathrm{T}$ were calculated according to the OD and the $E_{2}$ and $T$ standard curves. During the ovariectomy operation, 1 mouse died. During the tumour formation process, tumours in 2 mice in the control group and 1 mouse in the ovariectomized group did not grow. Thus, there were 10 available blood samples from each group. The analysis showed that the serum levels of $\mathrm{E}_{2}$ and $\mathrm{T}$ in the ovariectomized group decreased exponentially, whereas the $\mathrm{E}_{2} / \mathrm{T}$ ratio increased at certain times $(55.88 \pm 11.45$ 
Table 1. Serum oestradiol and testosterone $\begin{array}{lllll}\text { Group } & n & E_{2}\left(p g \cdot m^{-1}\right) & T(n g . m l-1) & E_{2} / T\end{array}$ levels in the control and OVX groups $(\bar{x} \pm$ s).

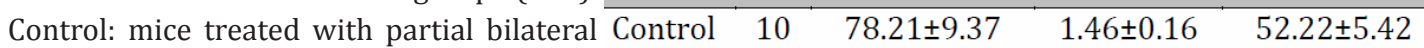
fat pad removal near the ovary; OVX: ovariectomized, mice treated with bilateral ova- OVX $\quad 10 \quad 55.88 \pm 11.45^{*} \quad 0.82 \pm 0.14^{*} \quad 69.62 \pm 14.43^{*}$ ry resection; ${ }^{*} P<0.005$.

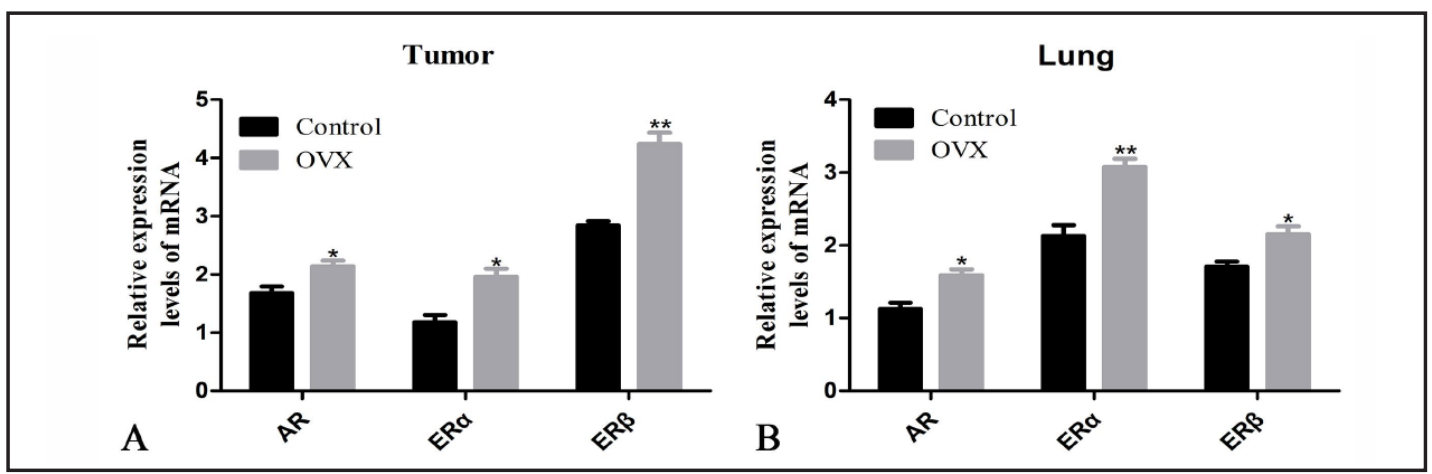

Fig. 3. Relative $A R, E R \alpha$ and $E R \beta$ mRNA expression levels in transplanted tumour and lung tissues from the control and OVX groups. Relative mRNA expression levels in transplanted tumour tissues from the two groups. B. Relative mRNA expression levels in lung tissues from the two groups. Control: mice treated with partial bilateral fat pad removal near the ovary; OVX: ovariectomized, mice treated with bilateral ovary resection; ${ }^{*} P<0.05,{ }^{*} P<0.01$.

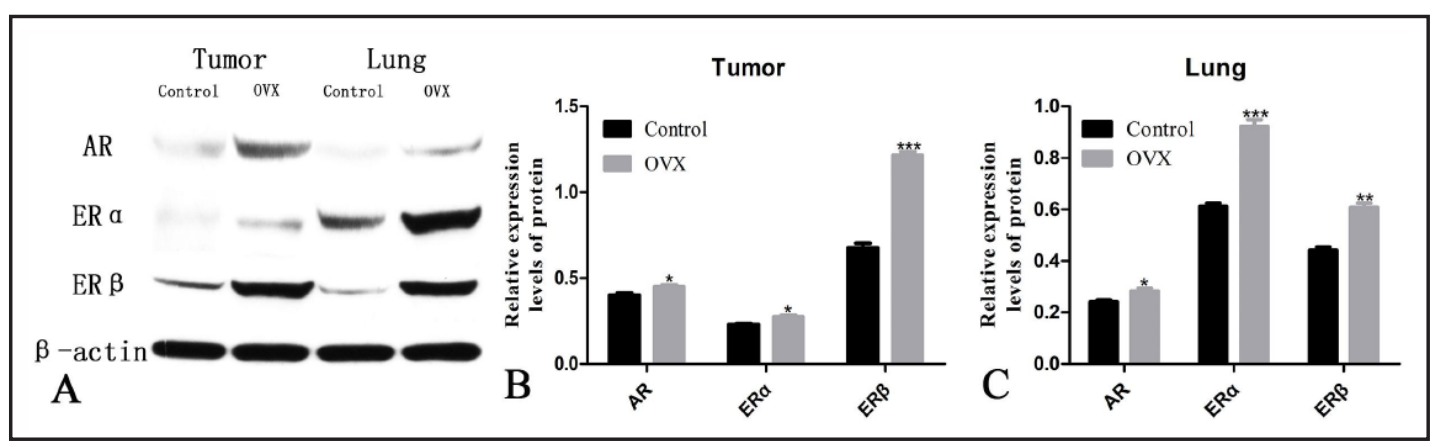

Fig. 4. Relative protein expression levels of $A R, E R \alpha$ and $E R \beta$ in transplanted tumour and lung tissues from the two groups. A, B, C. The protein expression levels were higher in the ovariectomized group than in the control group, especially for ER $\beta$ in transplanted tumour tissue and ER $\alpha$ in lung tissue. Control: mice treated with partial bilateral fat pad removal near the ovary; OVX: ovariectomized, mice treated with bilateral ovary resection; ${ }^{*} P<0.05,{ }^{* *} P<0.01,{ }^{* * *} P<0.001$.

and $78.21 \pm 9.37,0.82 \pm 0.14$ and $1.46 \pm 0.16,69.62 \pm 14.43 \pm 29.81$ and $52.22 \pm 5.42, P<0.05$ ) compared with the control group (Table 1).

\section{Differences in $A R, E R \alpha$ and ER $B R N A$ expression levels in transplanted tumour and lung tissues}

Total RNA was extracted from tissues, and the relative AR, ER $\alpha$ and ER $\beta$ mRNA expression levels in transplanted tumour and lung tissues are shown in Fig. 3. Expression levels in transplanted tumour tissues were higher in the ovariectomized group than in the control group, especially for ER $\beta$ mRNA $(P<0.01)$. Furthermore, expression levels were higher in lung tissues from the ovariectomized group than in those from the control group, with a significant increase in ER $\alpha$ mRNA expression levels $(P<0.01)$. The higher mRNA expression levels of $A R, E R \alpha$ and $E R \beta$ in the ovariectomized group may be associated with the low serum levels of $\mathrm{E}_{2}$ and $\mathrm{T}$, which led to the imbalance in the murine microenvironment.

\section{KARGER}


Fig. 5. $A R, E R \alpha$ and $E R \beta$ protein expression levels in transplanted tumour and lung tissues from the two groups (IHC, $\times 200$ magnification). A-D. AR protein expression levels. E-H. $\mathrm{ER} \alpha$ protein expression levels. I-L. ER $\beta$ protein expression levels. The protein expression levels in transplanted tumour and lung tissues were significantly higher in the ovariectomized group than in the

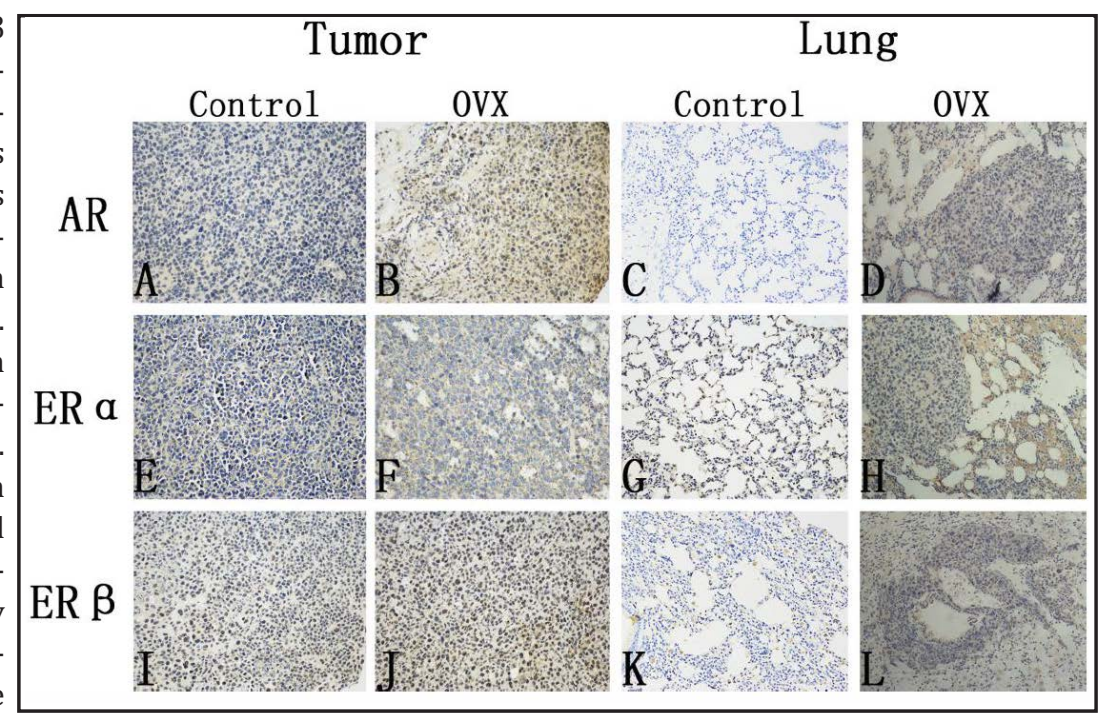
control group. In addition, ER $\beta$ protein expression in tumour tissue and ER $\alpha$ protein expression in lung tissue were obviously high. Control: mice treated with partial bilateral fat pad removal near the ovary; OVX: ovariectomized, mice treated with bilateral ovary resection.

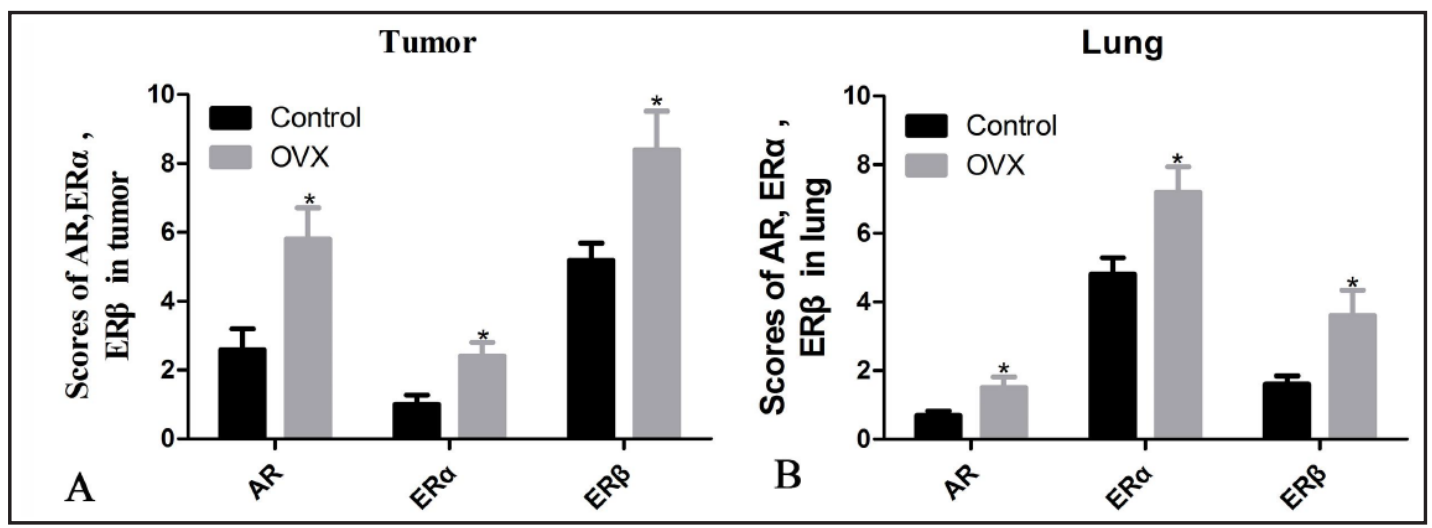

Fig. 6. AR, ER $\alpha$ and ER $\beta$ staining score by IHC analysis. The staining score was based on the staining intensity and the percentage of positively stained cells in transplanted tumour tissue (A) and lung tissue (B). Control: mice treated with partial bilateral fat pad removal near the ovary; OVX: ovariectomized, mice treated with bilateral ovary resection; ${ }^{*} P<0.05$.

Differences in AR, ER $\alpha$ and ER $\beta$ protein expression levels in transplanted tumour and lung tissues

According to the Western blot analysis, ER $\beta$ protein expression levels were highest in transplanted tumour tissues in both the control and ovariectomized groups $(P<0.0001$; Fig. 4). In lung tissues, ER $\alpha$ protein expression levels were highest in the ovariectomized group $(P<0.0001)$. The expression levels of AR, ER $\alpha$ and ER $\beta$ were clearly higher in the ovariectomized group than in the control group. The IHC results showed that AR, ER $\alpha$ and $\mathrm{ER} \beta$ staining was more evident in the ovariectomized group than in the control group (Fig. 5). Staining score analysis supported these observations and revealed that the ER $\beta$ protein expression score was highest in transplanted tumour tissue from the ovariectomized group $(P<0.05$; Fig. 6). In addition, in lung tissue, the ER $\alpha$ expression score was the highest $(P<0.05)$. The rates of high expression of AR, ER $\alpha$ and ER $\beta$ in lung and tumour tissues from the two groups indicated that tumour ER $\beta$ expression and lung ER $\alpha$ expression were significantly different in the ovariectomized group compared with the control group (both $P<0.05$, Table 2). Therefore, Western blot and IHC results revealed high expression of AR, ER $\alpha$ and ER $\beta$ in transplanted tumour tissue and lung tissue from ovariectomized mice. 


\section{Cellular Physiology Cell Physiol Biochem 2017;44:1425-1434 \begin{tabular}{l|l} 
and Biochemistry POI: 10.1159/000485538 & $\begin{array}{l}\text { (c) } 2017 \text { The Author(s). Published by S. Karger AG, Basel } \\
\text { www.karger.com/cpb }\end{array}$
\end{tabular} \\ Published onlıne: November 30, 2017 why}

Table 2. AR, ER $\alpha$ and ER $\beta$ expression in transplanted tumour and lung tissues from the control and OVX (ovariectomized) groups.

\begin{tabular}{|c|c|c|c|c|c|c|c|c|c|c|c|}
\hline \multirow{2}{*}{\multicolumn{2}{|c|}{ Tissue type }} & \multirow{2}{*}{$\mathrm{n}$} & \multicolumn{2}{|c|}{ AR expression } & \multirow{2}{*}{$P$} & \multicolumn{2}{|c|}{ ER $\alpha$ expression } & \multicolumn{4}{|c|}{ ER $\beta$ expression } \\
\hline & & & Pecitive & Norotix & & Poritix & Norative & $P$ & Pociting & Norative & $P$ \\
\hline \multirow{2}{*}{ Tumour } & Control & 10 & 3 & 7 & \multirow{2}{*}{0.36} & 4 & 6 & \multirow{2}{*}{0.37} & 4 & 6 & \multirow{2}{*}{0.02} \\
\hline & ovX & 10 & 5 & 5 & & 6 & 4 & & 9 & 1 & \\
\hline \multirow[b]{2}{*}{ Lung } & Control & 10 & 3 & 7 & \multirow[b]{2}{*}{0.64} & 4 & 6 & \multirow[b]{2}{*}{0.02} & 6 & 4 & \multirow[b]{2}{*}{0.33} \\
\hline & ovx & 10 & 4 & 6 & & 9 & 1 & & 8 & 2 & \\
\hline
\end{tabular}

\section{Discussion}

For half a century, the incidence and mortality of lung cancer have been increasing, and lung cancer is the leading cause of cancer-related death in most developed countries[2]. As the number of female smokers continues to increase, the ratio of male to female patients with lung cancer has risen rapidly. Oestrogens can signal through either ER $\alpha$ or ER $\beta$; these receptors are involved in numerous kinds of malignant tumours, including hormone-dependent tumours such as breast cancer[21] and prostate cancer[22]. However, many studies[23-25] have found that oestrogens and ER have significant effects on lung development and physiology, which provided a potential molecular mechanism for the gender differences in lung cancer. Thus, we performed this study to explore the previously unknown regulators of lung cancer.

Bilateral ovariectomy[26] was used to decrease sex hormones in mice in the ovariectomized group, and mice in the control group underwent partial removal of perinephric fat near the bilateral ovaries. Next, all mice were inoculated with a single cell suspension of Lewis lung cancer cells from C57BL/6 mice. Then, we observed significant differences between the control and ovariectomized groups in terms of body weight curves and transplanted tumour volume. In addition, the transplanted tumour weight of mice in the ovariectomized group was heavier than that in the control group $(1.83 \pm 0.40$ and $3.13 \pm 0.43$, $p<0.05)$. The serum analysis showed that the serum levels of $\mathrm{E}_{2}$ and $\mathrm{T}$ in the ovariectomized group decreased exponentially, while the $\mathrm{E}_{2} / \mathrm{T}$ ratio was increased at certain time points compared with the control group $\left(\mathrm{E}_{2}: 55.88 \pm 11.45\right.$ and $78.21 \pm 9.37 ; \mathrm{T}$ : $0.82 \pm 0.14$ and 1.46 \pm 0.16 ; ratio: $69.62 \pm 14.43 \pm 29.81$ and $52.22 \pm 5.42, p<0.05$ ). Further analysis of AR, ER $\alpha$ and ER $\beta$ mRNA and protein expression levels in tumour and lung tissues revealed higher expression in the ovariectomized group, particularly regarding ER $\beta$ in tumour tissue and $\mathrm{ER} \alpha$ in lung tissue. Therefore, ovariectomy decreased the serum levels of $\mathrm{E}_{2}$ and $\mathrm{T}$ and increased the $\mathrm{E}_{2} / \mathrm{T}$ ratio in mice, and the resulting imbalance in the internal environment promoted the growth of transplanted tumours. ER $\alpha$ and ER $\beta$ played key roles in this process.

Clinical studies[27, 28] support the conclusion that there is an imbalance in sex hormones and their receptors in patients with lung cancer. $\mathrm{E}_{2}$ levels were much higher in patients with lung cancer than in a normal control group, while T levels were lower in patients. In addition, several studies[29-31] have now reported that exposure to hormone replacement therapy (HRT) is associated with negative effects on lung cancer survival. Ganti et al[29] performed a retrospective chart review of women diagnosed with lung cancer and collected data including age, past history of cancer, HRT use and overall survival. They found that overall survival was significantly higher in patients without HRT compared with those who received HRT. HRT may affect the endocrine environment in such a way that promotes lung cancer.

The mechanism of lung tumourigenesis is complex, and lung cancer is mainly caused by various carcinogenic factors that cause gene changes and induce normal cells to become cancerous. However, it is not known how gene polymorphisms affect $\mathrm{E}_{2}$ metabolism[32]. The body of clinical trials suggests that the patients with lung cancer who respond well to EGFR 


\section{Cellular Physiology Cell Physiol Biochem 2017;44:1425-1434 \begin{tabular}{l|l|l} 
and Biochemistry & DOI: 10.1159/000485538 & $\begin{array}{l}\text { C } 2017 \text { The Author(s). Published by S. Karger AG, Basel } \\
\text { www.karger.com/cpb }\end{array}$
\end{tabular}

TKIs are mainly female, not male[33], which may indicate potential cross-talk in signalling between EGFR and ER in lung cancer[34,35]. Other studies found that abnormal ER expression is related to mutations in other genes. Both Mah V[16] and Marquez-Garban DC[36] reported that oestrogen and ER can activate the Src family of nonreceptor tyrosine kinases, MAPKs (mitogen-activated protein kinases) and PI3K (phosphatidylinositol-3 kinase), which affected cancer cell growth, proliferation and apoptosis. Thus, it will be worthwhile to study what affects the overexpression of ER-related receptors and subsequently promotes the formation of malignant tumours.

\section{Acknowledgements}

This research was supported by grants from the National Natural Science Foundation of China (81473497), the Social Research Project of Henan Provincial Science and Technology Department (132102310106), and the Natural Science Foundation of Henan Provincial Department of Education (12A320077).

\section{Disclosure Statement}

None.

\section{References}

$\checkmark$ Stinchcombe TE, Socinski MA: Considerations for second-line therapy of non-small cell lung cancer. Oncologist 2008;13 Suppl 1:28-36.

- Siegel RL, Miller KD, Jemal A: Cancer Statistics, 2017. CA Cancer J Clin 2017;67:7-30.

-3 Carter L, Rothwell DG, Mesquita B, Smowton C, Leong HS, Fernandez-Gutierrez F: Molecular analysis of circulating tumor cells identifies distinct copy-number profiles in patients with chemosensitive and chemorefractory small-cell lung cancer. Nat Med 2017;23:114-119.

4 Mostertz W, Stevenson M, Acharya C, Chan I, Walters K, Lamlertthon W, Barry W, Crawford J, Nevins J, Potti A: Age- and sex-specific genomic profiles in non-small cell lung cancer. Jama 2010;303:535-543.

-5 Youlden DR, Cramb SM, Baade PD: The International Epidemiology of Lung Cancer: geographical distribution and secular trends. J Thorac Oncol 2008;3:819-831.

6 Govindan R, Ding L, Griffith M, Subramanian J, Dees ND, Kanchi KL, Maher CA, Fulton R, Fulton L, Wallis J, Chen K, Walker J, McDonald S, Bose R, Ornitz D, Xiong D, You M, Dooling DJ, Watson M, Mardis ER, Wilson RK: Genomic landscape of non-small cell lung cancer in smokers and never-smokers. Cell 2012;150:11211134.

7 Comprehensive molecular profiling of lung adenocarcinoma. Nature 2014;511:543-550.

8 Swanton C, Govindan R: Clinical Implications of Genomic Discoveries in Lung Cancer. N Engl J Med 2016;374:1864-1873.

-9 Peng J, Xu X, Mace BE, Vanderveer LA, Workman LR, Slifker MJ, Sullivan PM, Veenstra TD, Clapper ML: Estrogen metabolism within the lung and its modulation by tobacco smoke. Carcinogenesis 2013;34:909915.

10 Dela Cruz CS, Tanoue LT, Matthay RA: Lung cancer: epidemiology, etiology, and prevention. Clin Chest Med 2011;32:605-644.

11 Gasperino J: Gender is a risk factor for lung cancer. Med Hypotheses 2011;76:328-331.

12 Lubin JH, Caporaso NE: Cigarette smoking and lung cancer: modeling total exposure and intensity. Cancer Epidemiol Biomarkers Prev 2006;15:517-523.

13 Doll R, Peto R, Boreham J, Sutherland I: Mortality in relation to smoking: 50 years' observations on male British doctors. BMJ 2004;328:1519.

14 Slowikowski BK, Lianeri M, Jagodzinski PP: Exploring estrogenic activity in lung cancer. Mol Biol Rep 2017;44:35-50.

15 Marquez-Garban DC, Chen HW, Fishbein MC, Goodglick L, Pietras RJ: Estrogen receptor signaling pathways in human non-small cell lung cancer. Steroids 2007;72:135-143. 


\section{Cellular Physiology Cell Physiol Biochem 2017;44:1425-1434

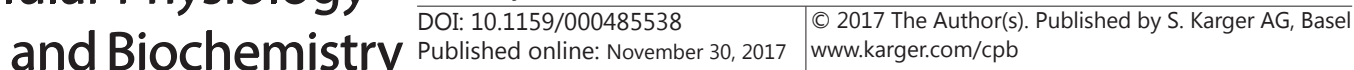

16 Mah V, Marquez D, Alavi M, Maresh EL, Zhang L, Yoon N, Horvath S, Bagryanova L, Fishbein MC, Chia D, Pietras R, Goodglick L: Expression levels of estrogen receptor beta in conjunction with aromatase predict survival in non-small cell lung cancer. Lung Cancer 2011;74:318-325.

17 Siegfried JM: Smoking out reproductive hormone actions in lung cancer. Mol Cancer Res 2014;12:24-31.

18 Zhang G, Liu X, Farkas AM, Parwani AV, Lathrop KL, Lenzner D, Land SR, Srinivas H: Estrogen receptor beta functions through nongenomic mechanisms in lung cancer cells. Mol Endocrinol 2009;23:146-156.

19 Schwartz AG, Wenzlaff AS, Prysak GM, Murphy V, Cote ML, Brooks SC, Skafar DF, Lonardo F: Reproductive factors, hormone use, estrogen receptor expression and risk of non small-cell lung cancer in women. J Clin Oncol 2007;25:5785-5792.

-20 Fan S, Liao Y, Liu C, Huang Q, Liang H, Ai B, Fu S, Zhou S: Estrogen promotes tumor metastasis via estrogen receptor beta-mediated regulation of matrix-metalloproteinase-2 in non-small cell lung cancer. Oncotarget 2017;8:56443-56459.

-21 Harbeck N, Gnant M: Breast cancer. Lancet 2017;389:1134-1150.

22 Latil A, Bieche I, Vidaud D, Lidereau R, Berthon P, Cussenot O, Vidaud M: Evaluation of androgen, estrogen (ER alpha and ER beta), and progesterone receptor expression in human prostate cancer by real-time quantitative reverse transcription-polymerase chain reaction assays. Cancer Res 2001;61:1919-1926.

23 Benninghoff AD, Williams DE: The role of estrogen receptor beta in transplacental cancer prevention by indole-3-carbinol. Cancer Prev Res (Phila) 2013;6:339-348.

-24 Patrone C, Cassel TN, Pettersson K, Piao YS, Cheng G, Ciana P, Maggi A, Warner M, Gustafsson JA, Nord M: Regulation of postnatal lung development and homeostasis by estrogen receptor beta. Mol Cell Biol 2003;23:8542-8552.

25 Morani A, Barros RP, Imamov O, Hultenby K, Arner A, Warner M, Gustafsson JA: Lung dysfunction causes systemic hypoxia in estrogen receptor beta knockout (ERbeta-/-) mice. Proc Natl Acad Sci U S A 2006;103:7165-7169.

-26 D'Eon TM, Souza SC, Aronovitz M, Obin MS, Fried SK, Greenberg AS: Estrogen regulation of adiposity and fuel partitioning. Evidence of genomic and non-genomic regulation of lipogenic and oxidative pathways. J Biol Chem 2005;280:35983-35991.

27 Xu Z, Liu J, Gu L, Ma X, Huang B, Pan X: Research progress on the reproductive and non-reproductive endocrine tumors by estrogen-related receptors. J Steroid Biochem Mol Biol 2016;158:22-30.

28 Zhou X, Cai W, Cao H: [Study on the relationship between estrogen receptor expression and level of serum sexual hormones in male patients with lung cancer]. Zhongguo Fei Ai Za Zhi 2002;5:349-351.

29 Ganti AK, Sahmoun AE, Panwalkar AW, Tendulkar KK, Potti A: Hormone replacement therapy is associated with decreased survival in women with lung cancer. J Clin Oncol 2006;24:59-63.

- 30 Chlebowski RT, Schwartz AG, Wakelee H, Anderson GL, Stefanick ML, Manson JE, Rodabough RJ, Chien JW, Wactawski-Wende J, Gass M, Kotchen JM, Johnson KC, O'Sullivan MJ, Ockene JK, Chen C, Hubbell FA: Oestrogen plus progestin and lung cancer in postmenopausal women (Women's Health Initiative trial): a post-hoc analysis of a randomised controlled trial. Lancet 2009;374:1243-1251.

-31 Bouchardy C, Benhamou S, Schaffar R, Verkooijen HM, Fioretta G, Schubert H, Vinh-Hung V, Soria JC, Vlastos G, Rapiti E: Lung cancer mortality risk among breast cancer patients treated with anti-estrogens. Cancer 2011;117:1288-1295.

32 Marshall AL, Christiani DC: Genetic susceptibility to lung cancer--light at the end of the tunnel? Carcinogenesis 2013;34:487-502.

33 Nose N, Sugio K, Oyama T, Nozoe T, Uramoto H, Iwata T, Onitsuka T, Yasumoto K: Association between estrogen receptor-beta expression and epidermal growth factor receptor mutation in the postoperative prognosis of adenocarcinoma of the lung. J Clin Oncol 2009;27:411-417.

-34 Yang SH, Mechanic LE, Yang P, Landi MT, Bowman ED, Wampfler J, Meerzaman D, Hong KM, Mann F, Dracheva T, Fukuoka J, Travis W, Caporaso NE, Harris CC, Jen J: Mutations in the tyrosine kinase domain of the epidermal growth factor receptor in non-small cell lung cancer. Clin Cancer Res 2005;11:2106-2110.

-35 Mazieres J, Rouquette I, Lepage B, Milia J, Brouchet L, Guibert N, Beau-Faller M, Validire P, Hofman P, Fouret P: Specificities of lung adenocarcinoma in women who have never smoked. J Thorac Oncol 2013;8:923-929.

-36 Marquez-Garban DC, Mah V, Alavi M, Maresh EL, Chen HW, Bagryanova L, Horvath S, Chia D, Garon E, Goodglick L, Pietras RJ: Progesterone and estrogen receptor expression and activity in human non-small cell lung cancer. Steroids 2011;76:910-920. 